\title{
BAGHDAD'S FALL AND ITS AFTERMATH Contesting the Central Asian Political Background and the Emergence of Islamic Mongol Dynasties
}

\section{Muhammad Abdul Karim}

State Islamic University (UIN) Sunan Kalijaga Yogyakarta, Indonesia email:profma.karim@gmail.com

\section{Abstract}

The sack of Baghdad is a dramatic event which was immediately followed by several key historical events, including the rise of Islamic Mongol. Founded by Chengiz Khan, the Mongol are the destroyer machine who previously ended the glory of Islam in $13^{\text {th }}$ century Middle East. A lot has been said concerning that dramatic siege, but little has been discussed regarding the continuation between the siege and the "reverse flow" of the Mongols as the unique events in the aftermath of the Baghdad's fall. The object of this paper is to examine the siege of Baghdad in the light of Central Asian frame and to explore the important events in the aftermath of the siege which are related to the rise of the Islamic Mongol Dynasties.

[ Jatuhnya Baghdad merupakan peristiwa tragis yang diikuti oleh sejumlah peristiwa lain, termasuk. munculnya kerajaan Mongol Islam. Dibawah kepemimpinan Chengisz. Khan, Mongol berhasil menggantikan kejayaan Islam di Timur Tengah abad ketigabelas. Banyak studi yang telah mengkaji peralihan tersebut, namun sedikit yang membahas kelanjutan proses tersebut dan arus balik Mongol pasca jatubnya Baghdad. Artikel ini membahas peraliban Baghdad dibawah konstelasi Asia Tengah dan peristiwa penting dibalik pendudukan Mongol bingga munculnya dinasti Islam Mongol.]

Keywords: Baghdad's fall, Central Asian context, fragmentation of the Mongols, Islamic Mongol dynasties. 


\section{A. Introduction}

In the study of the fall of Baghdad (1258 AD), the political-sphere of Medieval Central Asia, either before or after the city's destruction, has a place of honor. This macro-context deserves more exploration due to its marginalization in vast majority of scholarly attentions. The study of Baghdad's fall has gained enormous attention, but the historical curiosities remain unfinished. ${ }^{1}$ It is true that the decline of 'Abbāsid has inner and outer causes, but placing its siege in a geo-political frame, especially that of Central Asian perspective is one of the necessary supplement toward its comprehensive historical narration. Some leading Islamic historians, such as Hitti, ${ }^{2}$ Watt, ${ }^{3}$ Lewis, ${ }^{4}$ Strange ${ }^{5}$ and Savory ${ }^{6}$ have proposed complex analysis on what "historically" happened. Still, the accentuation on Central Asian geo-political frame and the complementary relation between Baghdad's Fall and the rise of Islamic Mongol in the aftermath, seem to be on the edge. In that case, Hasan Ibrahim Hasan is an exception, with certain accounts on Mongols, he successfully makes an attempt to explain the Baghdad's fall in a special angle, ${ }^{7}$ although he does not speak so much concerning the Mongol's conversion into Islam in this regard. One field remains observable is the political situation in

1 The study of 'Abbasid decline which culminated with the sack of Baghdad by Mongol invaders remains scholarly observed. By contemporary scholarship, the comprehensive picture of the siege has been developed along with the availability of the historical sources. On the contemporary research of Baghdad's fall see Hend Gilli-Elewy, "Al-awādi al-ğāmia: A Contemporary Account of the Mongol Conquest of Baghdad, 656/1258", Arabica, vol. 58, no. 5 (2011), pp. 353-71; Michael Cooperson, "Baghdad in Rhetoric and Narrative", Muqarnas, vol. 13, no. 1 (1996), pp. 99-113.

2 Philip K. Hitti, History of the Arabs (London: Macmillan, 1937), pp. 484-9.

3 W. Montgomery Watt, Kejayaan Islam: Kajian Kritis dari Tokoh Orientalis, trans. by Hartono Hadikusumo (Yogyakarta: Tiara Wacana, 1990), pp. 165-6.

${ }^{4}$ Bernard. Lewis, Arabs in History (Oxford: OUP Oxford, 2002), pp. 157-79; Bernard Lewis, "Abbāsids", Encyclopaedia of Islam, vol. 1, ed. by H.A.R. Gibb and et. al (Leiden: Brill, 1992), pp. 20-1.

5 G. Le Strange, Baghdad during the Abbasid Caliphate: From Contemporary Arabic and Persian Sources (New York: Cosimo Classic, 2011), pp. 340-4.

${ }^{6}$ Roger Savory, "Baghdad”, Encyclopaedia of Islam, vol. 1, ed. by H.A.R. Gibb and et. al (Leiden: Brill, 1992), p. 902.

7 Hasan Ibrahim Hasan, Tarikh al-Islam; al-Siyasi wa al-Dini wa al-Tsaqafi wa al-Ijtima’, vol. 4 (Beirut: Dar al-Jil, 1996), pp. 125-54. 
the aftermath of destruction, in which the fate of Mongols has entered a moment of departure.

The Central Asian perspective in explaining the fall of Baghdad, which marked the end of Islamic golden age, has a valuable account for several reasons. Long before the Arab domination, Central Asia has been regarded as the crossroad of the civilization. In the period of 250-750 $\mathrm{AD}$, for example, it witnessed the rise of several mighty empires; Sasanian, Gupta, Sui and Tang, and the Arab Caliphate. ${ }^{8}$ The period of 750-1500 $\mathrm{AD}$, the course of Central Asia has entered the Islamicate cases, to which the age of high achievements of the region was often credited by many historians. ${ }^{9}$ As the Arabs first crossed the Oxus in 653-4 AD, during the Caliphate of Uthmān and Mu'āwiya general, 'Ubaidillāh bin Ziyād, in $674 \mathrm{AD}$, defeated Bukhar Khudat, the local Sogdian ruler, ${ }^{10}$ a new page of history of Central Asia had just begun. In the affairs of Central Asia, the fall of Baghdad was one of the most important event, due to its engagement with the representative empires of that region, especially the Mongols and their unique story, psrticularly after the siege of Baghdad.

In this paper, I try to capture several major actors arround the fall of Baghdad within the Central Asian frame, including Khawarezm Empire, Assasins, and especially the Mongols. These representatives of Central Asian empires had a lot of things to do with the fall of Baghdad, contested Hülegü Khan as the major figure in that dramatic siege, along with the almost-forgotten Berke Khan, Hülegü's cousin who stood at the exact opposite. This paper can be seen as a additional footnote to the findings of previous historians on the same theme. The possible contribution is to make clear the legacy of Baghdad's fall in Central Asian political upheaval, to pose the events in the aftermath of the siege as an

8 The intensity of ethnic and cultural interaction is also proofed by the discovery of written sources in East Turkestan. B.A. Litvinsky and Zhang Gua-da, "Historical Introduction", in History of Civilizations of Central Asia The Crossroads of Civilizations: A.D. 250-750, vol. 3, ed. by B.A. Litvinsky, R. Shabani Samghabadi, and Zhang Gua-da (Paris: UNESCO Publishing, 1996), p. 19.

9 M.S. Asimov and C.E. Bosworth (eds.), History of Civilizations of Central Asia, vol. 4 (Paris: UNESCO Publishing, 2000).

${ }^{10}$ C.E. Bosworth, "The Appearance of the Arabs in Central Asia Under the Umayyads and the Establishment of Islam", in History of Civilizations of Central Asia, vol. 4, ed. by M.S. Asimov and C.E. Bosworth (Paris: UNESCO Publishing, 2000), p. 24. 
integral part of the meta-narration of Baghdad's fall, and to make some reinforcements to re-examine the Mongol's place in Islamic history.

\section{B. Central Asia Towards the Sack of Baghdad (1100-1256 AD); A Quadrilateral Tension}

The political sphere of Central Asia before the Baghdad's fall witnessed such a critical situation. Towards the siege of Baghdad, four substantial powers dominated political affairs of the region; 'Abbāsid family, Seljuq, Khwarezmian, and Mongol. By $13^{\text {th }}$ century, when the weakness of the 'Abbāsid was revealed, political stage contested Mongols from the east as the new prominent player. In 1206 AD, Temüjin (11621227 AD) was inducted as a new supreme lord of the Mongols in a greet meeting (quriltal) with the title Chengiz Khan. With a strictly disciplined army, he was able to make an extensive conquest. Mongols under Chengiz Khan occupied the major portion of Central Asia and China, including the present Afghanistan, Northern Persia, and the Caucasian border areas. ${ }^{11}$ The rising powerful empire had just prepared to sweep the world in the beginning of $13^{\text {th }}$ century under the rule of world-shaking leaders.

Along with that newly-established power, the previous prominent player was the Khwarezmian Empire which has been established since $1077 \mathrm{AD}$, as a rising power originated from a Seljuq province. Khawarezm province grew rapidly under the leadership of Anūştegin (1077-1097 $\mathrm{AD})$, the founder of the dynasty. His son, Qutb al-Din Muhammad (Muhammad I) was considered as the first Shah who ruled the province during 1097-1127 AD. The rebellion of Khwarezm was triggered by Muhammad's son, 'Alā al-Din Atsiz. After various rebellions, he finally declared the independence from Sultan Sanjar of Seljuq. When Sanjar died in 1157 AD, Seljuq domination in Persia ended. By 1204 AD, Khwarezmian Dynasty had established the power to match with the Seljuq. At its peak, the empire had successfully defeated almost all of Seljuq's subordinates, ranging from Caspian Sea to Bukhara and

11 Bertold Spuler, History of the Mongols: Based on Eastern and Western Accounts of the Thirteenth and Fourteenth Centuries, trans. by Helga Drummond and Stuart Drummond (London: Routledge \& Kegan Paul, 1972), p. 3. 
Samarqand. ${ }^{12}$

One of the most significant political upheaval before Baghdad's total destruction was the political tension between 'Abbāsid-SeljuqKhwarezm, in one hand, and the Mongols in the other. Hitti and al-Salabi highlighted one of the most important disputes contest the 'Abbāsid Caliph, al-Nāsir (1180-1225 AD), who incited Khwarezm-Shah IV, 'Alā al-Din Takash (1172-1200 AD) to attack the Seljuq of the Persian Iraq (Iräq al-'Ajam) to replace the authority. ${ }^{13}$ One should note that at the end of its period, the 'Abbāsid political power was limited in Baghdad and surrounding areas, while the sovereignty outside Baghdad was held by Seljuq political authority and later was also challenged by the Khwarezmian. During several years, the armed conflict happened between two opposite power, until the last battle between Takash of Khwarezm and Tughril of Seljuq occurred in $590 \mathrm{AH} / 1194 \mathrm{AD}$ with the defeat of the Seljuq which eventually marked its major collapse. Tughril's head was sent to Baghdad and displayed there for several days. ${ }^{14}$

After Takash's victory, Caliph al-Nāsir asked the vacation of some territories in Iraq, but Takash refused to do that. Not just ignored the caliph's request, he even issued coins bearing his name as sultan and proposed the authority over Baghdad. ${ }^{15}$ Juzjānī's account reported that a disloyalty showed by Takash towards the caliph caused the armed battle wich was triggered by Baghdad's authority who sent a vizier to repel Takash in Iraq, although the vizier was defeated and eventually returned

12 Syams al-Din al-Zahabi, al-'Tbar fi Khabari Man Ghabar, vol. 2 (Beirut: Dār al-Kutub 'Ilmiyyah, 1985), pp. 362, 444; Abu al-Fidā, Tārikh Abi al-Fidā' al-Musammā bi al-Mukhtasar fi Akhbār al-Basyar, vol. 3 (Cairo: al-Matba'ah al-Husainiyya al-Mishriyya, 1907), p. 118; Bertold Spuler, "The Disintegration of the Caliphate in the East", in The Cambridge History of Islam, vol. 1A, ed. by P.M. Holt et al. (Cambridge: Cambridge University Press, 1977), pp. 157-9.

13 Hitti, History of the Arabs, pp. 481-2; 'Ali Muhammad al-Salabi, al-Ayyubiyyun ba’da Salāh al-Din (Beirut: Dār al-Ma’rifah, 2001), p. 270.

14 al-Fidā, Tärikh Abi al-Fidā' al-Musammā bi al-Mukhtasar fi Akbbār al-Basyar, vol. 3: pp. 89-90; Abū al-Fidā Ismā’il Ibn Kathīr, al-Bidāyah wa al-Nihāyah, vol. 13 (Giza: Hijr li al-Tiba'ah wa al-Nasyr, 1998), p. 664.

15 Hitti, History of the Arabs, p. 482. 
to Baghdad. ${ }^{16}$

In such a tension, the key player was also attributed the the worldshaking Chengiz Khan, the founder of Mongol Empire. By the rising of Mongols, the stage of Central Asian political-sphere has entered a new phase that never happened before. Along with political upheavals between the major empires in Central Asia, all-conquering forces from the East joined the game they have never loose. In that upheaval, a troublemaker from a mountaintop fortress called Hasyasyin or Assasins, is worthy of mention. After the great internal conflict within the Isma'ilism, they split into two major divisions; Nizāriyya and Musta'lawiyya. While the Musta'lawi or the Western Ismā'ilis who continued the traditions of Fatimid has never acquired any particular political power, the Nizāris or the Eastern Ismā'ilis founded a vigorous state in Persia. ${ }^{17}$ This Ismā'ili movement were famously well-known as the Assassins to the Medieval Europeans, under the leadership of Hasan-i Sabbah (d. 1124) with the mountainous fortress of Alamut as their campsite. This secret order was very disturbing in Persia and the surrounding areas, both for the SunniSeljuq authority and for Mongolian regions under Chengiz Khan. ${ }^{18}$ These political upheavals were key events that preceded and eventually led to the destruction of Baghdad.

\section{Otrar Incident and the Gate of Catastrophic Disaster}

In its fragile time, Abbasid palace was surrounded by threats. As noted by Lewis, when the weakness of Abbasid was revealed since $11^{\text {th }}$ century, the series of attack from internal and external invaders took place. The wave of reconquista culminated with the advent of the crusaders in the Near-East. In Africa, a new religious movement resulted the new Berber empire in Southern Morroco and Senegal-Niger. Another wave of unexpected invaders came from Central and East Asia with permanent effect, the Turks and the Mongols. ${ }^{19}$ Along with those waves of invader,

16 Minhāj Sirāj Jūzjānī, Tabaqāt-i-Nạsiriri, vol. 2, trans. by H.G. Raverty (New Delhi: Mrs Nirmal D. Jain for Oriental Books Reprint Corporation, 1970), p. 243.

17 Farhad Daftary, The Ismäilis: Their History and Doctrines (Cambridge: Cambridge University Press, 1990), p. 2.

18 Ibid., pp. 2, 417.

19 Lewis, Arabs in History, p. 159. 
Baghdad has also the surrounding "fortress", namely the autonomous states which acknowledged the nominal sovereignty of the 'Abbāsid as Commander of the Faithful. To face the crusades, the Ayyubid Sultanate ${ }^{20}$, the Caliph "fortress" in the the levant, while in the Central Asian, the Mongols had to face the Khwarezmian empire before reaching Baghdad's palace.

It is important to note that at the late of $12^{\text {th }}$ Century and the Early of $13^{\text {th }}$ Century, one of the most powerful and mighty Muslim rulers with de facto political authority was the Khawarezm-Shah, whose territory covered almost all of Central Asia. By 1210 AD, the Mongol massive forces appeared in Semirechye, and Khwarezmian authority was established in Transoxiana. When Qara-Khitay of Transoxiana submitted their power to Chengiz Khan in 1218 AD, his territory was bordered directly with the Islamic Khwarezmian Empire under 'Alā alDin Muhammad, son of Takash. ${ }^{21}$ By that time, Khwarezm-Shah and Chengiz Khan became the greatest rulers to cover the Central Asia. Although it is very natural when the two rulers became rivals, Chengiz Khan first considered Khwarezm-Shah as the sovereign of the sun-set, as he declared himself as the sovereign of the sun-rise. ${ }^{22}$

The Great-Khan at that time had no intention of invading Khwarezm Empire and was only interested in trade and even a potential alliance. As pointed out by Sevim and Bosworth, the relation between him and Chengiz Khan has been started since 1215 AD, when 'Alā al-Din Muhammad sent an embassy to the Mongol-Khan in northern China. Besides, there was also an indecisive military encounter between Muhammad's forces and Jöchi, Chengiz' eldest son in the north of the Aral Sea. ${ }^{23}$

The immediate cause of large-scale intervention and catastrophic

20 Ayyubid Sultanate is reported to has submitted the acknowledgement to the nominal authority of the caliph. See Hasan, Tarikh al-Islam, vol. 4, pp. 101-12.

21 Sh. Bira, "The Mongols and Their State in the Twelfth to the Thirteenth Century", in History of Civilizations of Central Asia, vol. 4, ed. by M.S. Asimov and C.E. Bosworth (Paris: UNESCO Publishing, 2000), p. 252.

22 Jūzjānī, Tabaqāt-i-Nāṣirì, 2: 966.

23 A. Sevim and C.E. Bosworth, "The Seljuqs and the Khwarazm Shahs", in History of Civilizations of Central Asia, vol. 4, ed. by M.S. Asimov and C.E. Bosworth (Paris: UNESCO Publishing, 2000), p. 177. 
invasion in Transoxiana by the Mongols was the execution of Chengiz' envoys at City of Otrar (located in modern Kazakhstan) in 1218 AD by Khwarezmian governor, Inalchuq or Ināl/Gāyir-Khān, a kinsman of the Sultan's mother. ${ }^{24}$ As narrated by Ibn Khaldun, Chengiz Khan's initial goal was to establish trade cooperation between two regions. When the Mongol merchants arrived at Otrar, Inalchuq told the Sultan that they were not merchants but Mongol spies in Khawarizm to watch out for. He finally killed them and took all the merchandise. ${ }^{25}$ This news reached Chengiz Khan by a merchant who escaped from Otrar prison. ${ }^{26}$ Chengiz Khan immediately sent a messenger to the Sultan asking the Governor to be punished in Mongol grass land by the Great Khan himself. However, the Sultan responded to Chengiz Khan's demands by killing the envoy. ${ }^{27}$ It was ultimately the gate opener for the full violence of Mongol military in the later part of $1219 \mathrm{AD}$.

In another extent, the disputes between Khwarezm and Baghdad were worst end. After occupying most of mountainous regions (biläd aljibā̄l) in Persia including Qazwin, Zanjān, Isfahān, and Hamadzān (1210 AD), Bukhārā, Samarqand, and seizing Ghazni (1214 AD), Muhammad decided to eliminate the 'Abbāsid and planned to maintain the 'Alid one. ${ }^{28}$ By $1217 \mathrm{AD}$, a year before Otrar incident, Muhammad was ready to march westwards. In that time of being threatened, as Hitti points out, the caliph asked for help to Chengiz Khan. ${ }^{29}$ However, based on Abu al-Fidā's account, Muhammadıs plan to overthrow Baghdad was eventually canceled for several reasons, including the emergence of bad weather that caused the dead of their animals, in addition to the report of the Mongol's appearance in the eastern fringes. They finally returned

24 'Ata-Malik Juvaini, Genghis Khan: The History of the World Conqueror, trans. by J.A. Boyle (Manchester: Manchester University Press, 1997), p. 79.

25 'Abdurrahmān Ibn Khaldūn, Tärikh Ibn Khaldūn, vol. 5 (Beirut: Dar Al-Fikr, 2000), p. 586.

26 'Juvaini, Genghis Khan, p. 80.

27 Khaldūn, Tärikh Ibn Khaldūn, vol. 5, p. 586.

28 al-Fidā, Tärikh Abi al-Fidä’ al-Musammä bi al-Mukhtasar fi Akhbār al-Basyar, vol. 3, p. 118; Hitti, History of the Arabs, p. 482.

${ }^{29}$ Hitti, History of the Arabs, p. 482. This point, however, has been questioned by some historians for not being conformed by the contemporary account. See Spuler, "The Disintegration of the Caliphate in the East", vol. 1A, p. 161. 
to Khurasān $n^{30}$ preparing to face Mongol invading armies who avenged for the Otrar incident.

Shortly speaking, during 1219 to 1221 AD, hundred of thousands of Mongol invaders under Chengiz Khan destroyed the empire with several stages of attack resulting the fall of major cities such as Otrar, Bukhārā, Samarqand, Jurjān and Khurasan. Muhammad died in despair at the coast of Caspian Sea after fleeing the Mongol attack on Samarqand in 1220 AD. Muhammad's son, Jalāluddin became the next Sultan who tried to recover the power. On the way of fleeing from the Mongols to India, he was defeated by Chengiz Khan in the Battle of Indus River in $1221 \mathrm{AD}^{31}$ This event had principally marked the end of Khwarezmian domination in Central Asia, although the official end of the dynasty occurred in $1231 \mathrm{AD}$ when Jalāluddīn was killed. ${ }^{32}$

\section{Before Reaching Baghdad}

The fall of Khwarezm Empire means the destruction of the one and only strong "fortress" between the Mongols and the Abbasids. A new friendship between Baghdad-Karakuram against Khiva, the capital of Khawarezm was like cutting the vein for the weakened power of the Abbasid. Two decades later, starting from the westward campaign to demolish the Assassin, the descendants of Chengiz Khan embarked upon the greatest conquest of history in the heartland of Islamic world.

When Chengiz Khan died in $1227 \mathrm{AD}$, the vast Mongolian territory was inherited to his heirs; Jöchi, Chagatai, Ögedei, and Touli. Ögedei was appointed as the Great Khan in Karakuram (the Mongol capital). The territory of Siberia and Russia was given to Jöchi whose descendants

30 al-Fidā, Tärikh Abi al-Fidā' al-Musammā bi al-Mukbtasar fi Akhbār al-Basyar, vol. 3, p. 118.

31 Khaldūn, Tärikh Ibn Khaldūn, vol. 5, pp. 586-90; Juvaini, Genghis Khan, pp. 81-141.

${ }^{32}$ After his defeat in Indus, Jalāluddin escaped to India to ask for political asylum although was rejected by Sultan Iltutmish. He then recovered the power to revive the Khwarezm Sultanate. He conquered several cities in Persia such as Azerbaijan, Tabriz, and Isfahan. In that attempt, he was defeated by Sultan Kayqobad of Seljuk-Rum in $1230 \mathrm{AD}$ and then fled to Diyar Bakr until he was eventually killed by a Kurdish in the following year. His death marked the "official" end of the Kwarezm Dynasty. See al-Fidā, Tärikh Abi al-Fidä’ al-Musammä bi al-Mukhtasar fi Akbbär al-Basyar, vol. 3, pp. 147-51. 
founded the Golden Hordé Dynasty. Chagatai acquired the territory of Khwarezm and eventually established the Chagatai Dynasty. The Neareastern region was given to Touli whose descendants transformed the region into the Ilkhan Dynasty. ${ }^{33}$

Another reason of the destruction of Baghdad is worthy of mention, namely the disruption of the Assassins. Started from the policy of Möngke, the Fourth Great-Khan (1248-1259 AD) to expand the Mongol empire, Hülegü was ordered to conquer Iran and al-Ajam (including modern Iraq, Syria, Armenia, and surrounding areas) while Kubilai was ordered to conquer the plains of China. ${ }^{34}$ In this case, Möngke's first instruction was to destroy the Isma'ili Assasins in their forts, Baghdad was to be destroyed only when the caliph refuse to submit his power. ${ }^{35}$ William Rubruck, a Fransiscan missionary and explorer who visited to the court of Möngke reported that in $1253 \mathrm{AD}$, four hundreds Assassins had made their way to killing the Great Khan. ${ }^{36}$ From that time, Möngke ordered to demolish these terrorists by sending his younger brother, Hülegü to campaign westward. After attacking Assassin several times, he finally succeeded in paralyzing their power center in Alamut. ${ }^{37}$

As Hitti notes, the main cause of the 'Abbāsid's fall is basically due to the weakness of the palace itself caused by the «centrifugal facton», including the internal political upheaval, decentralization, exploitation, over-taxation, and the like. ${ }^{38} \mathrm{It}$ is in this political turmoil that Baghdad has finally met the final downfall and it destroyed easily by the all-conquering Mongols.

33 David Morgan, The Mongols (Cambridge: Wiley-Blackwell, 1993), p. 8.

34 Jūzjānī, Tabaqāt-i-Nāṣirì, vol. 2, p. 1225; Juvaini, Genghis Khan, p. 607; Bernard Lewis., Islam from the Prophet Mubammad up to the Capture of Constantinople, vol. 1 (New York: Harper Torchbook, 1974), p. 78.

35 J.A. Boyle, "Dynastic and Political History of the Il-Khāns", in The Cambridge History of Iran, vol. 5, ed. by J.A. Boyle (Cambridge: Cambridge University Press, 1968), p. 340 .

36 Willem van Ruysbroeck, The Mission of Friar William of Rubruck: His Journey to the Court of the Great Khan Möngke, 1253-1255, trans. by Peter Jackson (London: Hakluyt Society, 1990), p. 222.

37 Rashīd al-Dīn Ṭabīb, Jāmi‘a al-Tawärikh Rashidi, vol. 1 (Qum: Wizārah alTsaqāfah al-Irsyād al-Qaumi), pp. 248-59.

38 Hitti, History of the Arabs, pp. 483-4. 
There is a seizure of opinion in the historical narrative on the reason of the Hülegü's attack to Baghdad. Rasyìd al-Dīn reported that a few times after the Assasin's destruction, a letter was sent by Hülegü to Caliph al-Musta'șim, which stated the Hülegü’s disappointment over caliph's reluctant to cooperate with the Mongols in eradicating "the castles of infidels", ${ }^{39}$ which according to several historians, refer to the Assasins. ${ }^{40}$ It is reported in the letter that Hülegü had previously asked the caliph to send reinforcements while conquering the Assassin in their castles, those who have become the common enemies for both leaders. However, despite supporting the Mongols, the caliph did not send his troops, which led to Hülegü's threatening to him; "beware of hatred and adversity, don't hit the kettle with your hand, and don't smear the sun with mud, you shall be tired". ${ }^{4}$

Here, the role played by Mu'ayyid al-Din al-'Alqami, a Shi'ite vizier of the 'Abbāsid, is worthy of mention. Another source states that Hülegü's letter containing his request to the reinforcement in the siege of Assasin's castles, fell to al-'Alqami. As a Shi'ite who did not want to eradicate his fellows, he replied to Hülegü's letter on behalf of the Abbasid Caliph at Baghdad with a bad language. Hülegü felt ridiculed, insulted, and his intentions was not appreciated. ${ }^{42}$ Juzjānī, a Sunni historian, describes that he was a "vizier of bad religion" who also made some tricks to destroy the palace including the collusion with Hülegü. One of his motivations was a desire to revenge against Amir Abu Bakr, son of the caliph and Musa-i Ja'far who slain and despoiled his fellow Shi'ites in Karkh and Mash-had. ${ }^{43}$ Narratives from Rasyid al-Din and Ibn al-Fuwāti, place al'Alqami's collusion with Hülegü as the rumor caused by the grass-root impact of his disputes with Mujāhid al-Din Aybak, related to diplomatic

39 Rashīd al-Dīn Ṭabīb, Jāmi'a al-Tawärikh Rashidi, vol. 2 (Qum: Wizārah alTsaqāfah al-Irsyād al-Qaumi), p. 264.

40 M. Lutfur Rahman, Islam (Dhaka: Bangla Academy, 1977), pp. 286-90; Ahmed Ashrafuddin, Maddhajuger Muslim Itihas (1258-1800) (Dhaka: Nawrose, 1976), pp. 64-5.

41 Țabīb, Jämi' a al-Tawärikh Rashidi, vol. 2, p. 268.

42 Rahman, Islam, pp. 287-90; Ashrafuddin, Maddhajuger Muslim Itihas (12581800), pp. 64-5.

43 Jūzjānī, Tabaqāt-i-Nāṣirì, vol. 2, pp. 1230-2. 
steps of the caliph to face the Hülegü's threat. ${ }^{44}$ Shi'ite historians proposed a different opinion. Ibn Tiqtiqa, for example, argued that the allegations aimed at al-'Alqami were not proven. He describes al-'Alqami as the excellent statesman favored by the caliph. However, it was the court's officials and the caliph's family, who hated him so much and spread the rumors and defamations about him. ${ }^{45}$

Regardless the huge controversy associated with al-'Alqami, the basic motivations of Mongol's assault on Baghdad was primary based on a common pattern in the history of civilization. This could be some, particular motivations underpinning their movement, but the greatest aim as commonly found in the expansion of other empires was the desire to rule. This policy was not issued without reasons. Back to Genghis Khan time, there were some contacts between Mongols and 'Abbāsid, including the caliph's attempt to make an alliance with Genghis Khan to solve the Khwarezmian's threats to Baghdad.

These pre-Baghdad's fall encounters ware recorded in Juzjānī's account ${ }^{46}$ and also revealed by the research of modern historians such as Grousset, Woods, and Nicolle. Two decades before the siege, the attempt has been made by Genghis Khan's first successor, Ögedei (1229-1241 $\mathrm{AD})$, to attack the 'Abbāsid territory. In $1224 \mathrm{AD}$, he threatened the caliph of Baghdad with invasion. ${ }^{47}$ Three years before (1221 AD), the expedition of two Chengiz Khan's generals, Jebe and Sübötäi was on the point of marching around Baghdad to destroy the Abbasid caliphate. This plan was eventually undone, due to their return to bold Hamadan. ${ }^{48}$ After establishing the authority over Western Iran including Kerman, Fars, Iraq 'Ajami, and Azarbaijan, numerous Mongol attempts to capture Isfahan were launched until that city finally fell in $1237 \mathrm{AD} .{ }^{49}$ Some raids

44 Țabīb, Jāmi‘a al-Tawārikh Rashidi, vol. 2, pp. 273-5; Gilli-Elewy, "Al-awādi al-ğāmia”, pp. 360-1.

45 Muḥammad b. Alī Ibn al-Ṭiqțaqā, al-Fak'rī fì al-Adāb al-Sultānìyya wa-al-Duwal al-Islāmiyya (Beirut: Dār Șādir, 1980), p. 338.

46 Jūzjānī, Tabaqāt-i-Nāṣirì, vol. 2, pp. 1225-8.

47 René Grousset, The Empire of the Steppes: A History of Central Asia, trans. by Naomi Walford (New Brunswick: Rutgers University Presss, 1970), p. 261.

48 Ibid., p. 245.

49 John E. Woods, "A Note on the Mongol Capture of Ișfahān”, Journal of Near Eastern Studies, vol. 36, no. 1 (1977), pp. 49-51. 
from the Mongols also reached Iraq in following year, but it was again defeated by the Caliph near Samarra. ${ }^{50}$

Finally, the plan for seizing Baghdad was a part of the next Great Khan's policy to expand Mongol authority established over Mesopotamia, Syria, and Persia. For this purpose, Möngke, the Fourth Great Khan (1251-1259 AD) gave this task to his young brother, Hülegü Khan to move westward. In this case, he was charged with the task of sacking two spiritual powers; the Isma'ili Assasins in Alamut and the 'Abbāsid Caliphate in Baghdad before finally conquering Syria. ${ }^{51}$

\section{E. The Siege and Its Aftermath}

\section{Berke Khan's Resistance to the Hülegü's Execution of the Caliph}

After the ultimate victory over the Assasins, on 19 January 1258 AD with 200.000 soldiers, Hülegü crushed Baghdad. John Masson Smith reconstruct the campaign from various Islamic sources as follow:

Hülegü started for Baghdad from Qazwin in March 1257. The direct distance is 511 miles $(823 \mathrm{~km})$. The journey was complicated, however, by diversions. Hülegü reached Dinavar on 26 April, and then decided to go to Tabriz. He came back to Hamadan on 26 July and returned to Tabriz. He next reached Hamadān on 21 September, and finally set out for Baghdad. ${ }^{52}$

Chengiz Khan's grandson, Hülegü, destroyed Baghdad in several attacks. Historians recorded that he did a lot of destruction and reported to had killed numerous people with variety of numbers. ${ }^{53}$ This siege eventually forced the caliph to surrender on January 10, 1258 AD. Baghdad was plundered for several days. Ten days later, the caliph and hundreds of qādi were all put to death. The majority of Baghdad's population were erased from the existence. In the hands of the Mongol

${ }^{50}$ David Nicolle, The Mongol Warlords: Genghis Khan, Kublai Khan, Hulegu, Tamerlane (New York: Firebird Books, 1990), p. 101.

51 Grousset, The Empire of the Steppes, p. 353.

52 John Masson Smith Jr, "Hülegü Moves West: High Living and Heartbreak on The Road to Baghdad", in Beyond the Legacy of Genghis Khan, ed. by Linda Komaroff (Leiden: Brill, 2006), p. 117.

53 See Kathīr, al-Bidāyah wa al-Nihāyah, vol. 13, pp. 233-6. 
Army, Baghdad was burned and looted in forty days. ${ }^{54}$

Here, the moment of departure must be employed. Along with Hülegü's campaign to demolish Baghdad, one of the major part of the Mongol's fragmentation came on the scene. Once before the siege of Baghdad, Berke Khan (d. 1266 AD), son of Jöchi in Golden Hordé, converted to Islam. This eventually marked the split in the creed, faith and ideology, in addition to the split in the vast Mongol's territory into four regions as it has already been explained. This departure was voiced from the Mongol khanate under Jöchi's family. Its region stretched from Russia to several Eastern European regions, such as Poland and Hungary. Some areas of Central Asia were also covered by its power, such as Azerbaijan and Samarqand. The Golden Hordé was founded by Berke's old brother, Batu Khan, Jöchiss first son, near the Volga River. His central government known as the Old Șarai. Since the reign of Berke Khan (1257 AD), the administrative center was moved 150 miles to the north city known as the New Șarai. He was the first Mongol leader to accept and establish Islam in Mongol state. Berke's leadership at the Golden Hordé has marked a new chapter in Mongol and Islamic history.

There are several opinions concerning his conversion into Islam. In Juzjānì's account, Berke was a Muslim since the time he was born, based on Jöchi's will to make his son a true Muslim..${ }^{55}$ Some scholars argue that he embraced Islam in 1251/2 AD. Abdul Ghazi, as cited by Thomas W. Arnold, states that Berke converted to Islam after he ascended the throne of Golden Hordé. He once accompanied the caravan from Bukhara and was flanked by two Muslim traders. He wondered so much about Islam and all of its accounts. His questions were greeted with some beautiful explanations that make him voluntarily converted to Islam. ${ }^{56}$

Another explanation regarding his conversion was also related to the esotericism argument. Hamid Algar mentioned the role of Sufi's, especially those who belonged to Kubrāwiyyah Sufi Order, in the conversion of Mongol rulers, including Berke Khan and Ghazan Khan. At that time, Kubrāwiya was one of the major sufi orders concentrated

\footnotetext{
54 Ṭabīb, Jāmi‘a al-Tawārikh Rashidi, vol. 2, pp. 290-4.

55 Jūzjānī, Tabaqāt-i-Nāṣirì, vol. 2, pp. 1283-4.

56 Thomas Walker Arnold, The Preaching of Islam: A History of the Propagation of the Muslim Faith (London: Constable and Company, 1913), pp. 227-8.
} 
in Central Asia. It is said that Berke converted in Bukhārā in a wellendowed khanqah established by Syaikh Saifuddin Bakharzi (d. 1260 AD), the famous disciple of Najm al-Din Kubrā (d. 1221 AD), the founder of Kubrāwiyya Sufi order who died during the Mongol's conquest of Khwarezm. ${ }^{57}$ Deweese and Arnold have proposed comprehensive narration on Berke's conversion. ${ }^{58}$ However, the most important thing is the consequence of his conversion which politically led him to federate with Muslim rulers and fight against his fellow Mongols, especially the Ilkhan troops under the command of his cousin, Hülegü Khan. In addition, the historical fact that he was the first Muslim ruler in the Mongols realm who officially established Islam in the dynasty ${ }^{59}$ must be taken into consideration.

In this elucidation, Ashrafuddin Ahmed cited the source which states that Berke protested against the Mongol's campaign to Baghdad. He even advised Hülegü to withdraw these troops. This happened due to the religious difference and bilateral politics; the friendship, political cooperation, and trade between Berke and the Abbasid Caliph alMusta'șim in Baghdad and later, between Berke and Mamluk Sultanate, Egypt. However these muslims are the political enemies of Hülegü. ${ }^{60}$

On the contrary, several historians reported detailed narratives on Hülegü's troops in which Berke's army had also participated in the campaign. ${ }^{61}$ This indicated that Berke had sent the reinforcements to Hülegü who had previously requested assistance to the Golden Hordé

57 Hamid Algar, "Introduction", in The Path of God's Bondsmen from Origin to Return, trans. by Hamid Algar (New York: Caravan Books, 1982), p. 4; Haji Muhammad Bukhari Lubis, "The Role of Sufis in Vonverting the Mongols into Islam", Islamiyyat, vol. 8 (1987), pp. 19-20.

58 Devin DeWeese, Islamization and Native Religion in the Golden Horde: Baba Tükles and Conversion to Islam in Historical and Epic Tradition (Pennsylvania: The Pennsylvania State University Press, 2007), pp. 81-5; Arnold, The Preaching of Islam: A History of the Propagation of the Muslim Faith, pp. 218-30.

59 DeWeese, Islamization and Native Religion in the Golden Horde, p. 3; Ruysbroeck, The mission of Friar William of Rubruck, p. 127.

60 Ashrafuddin, Maddhajuger Muslim Itihas (1258-1800), p. 85.

61 Mūsā ibn Muhammad al-Yūnīnī, Zail Mir'āt al-Zamān, vol. 1 (Cairo: Dar al-Kitab al-Islamī, 1992), p. 80; Abū al-Mahạāin Yūsuf Ibn Taghrībirdī, al-Nujūm alZähirah fi Mulük. Misr wa al-Qähirah, vol. 7 (Cairo: Maṭba'a 'Dār al-Kutub wa-al-watā'iq al-qawmiyya', 1971), p. 49. 
in the attempt to attack Baghdad. Nevertheless, when a dispute arose between Berke and Hülegü which culminated in 1262 AD, Golden Hordé troops were ordered to flee. Some of these soldiers eventually arrived in Egypt in that year and sought asylum in Baybar's region (musta'minin). They were treated well by the Sultan, ${ }^{62}$ due to the newly-declared coalition between him and Berke to restrain Hülegü ${ }^{63}$ in the Levant and Caucasus. In this case, not only sent the moral aid, the Khan of Golden Hordé had also conformed Baybar's offers to make a coalition, marked by political marriage, against the infidel Hülegü who has become the common enemy. ${ }^{64}$

Berke's conversion to Islam has become one of the reasons for that internal disputes. After the invasion of Baghdad and the caliph's execution, the relationship between Hülegü and Berke became more inharmonious. It simply aroused Berke, a Muslim Khan, to take action. ${ }^{65}$ Hülegü's execution to Berke's envoys has also led to the escalation of tension. ${ }^{66}$ This internal strife culminated by their disputes in sovereignty of several regions in $1262 \mathrm{AD} .{ }^{67}$ In turn, this led to the open war between two Mongol leaders.

However, despite variety historical records, what is clear is that Berke disagreed with Hülegü's plan to execute the caliph of Islamic world. Rasyīd al-Dīn narrated Berke's anger to Hülegü as follows:

He has sacked all the cities of the Muslims and has brought about the

\footnotetext{
${ }^{62}$ Kathīr, al-Bidāyah wa al-Nihāyah, vol. 13, p. 270.

63 One year earlier, 659 AH/1260-1, the news about Berke's conversion reached
} Baybars. He immediately sent a letter to Barke to cooperate in fight against Hülegü which finally resulted the coalition. Taqiaddīn Ahmad b. 'Alī al-Maqrīzī, al-Suluk li Ma'rifat Duwal al-Muluk, vol. 1 (Beirut: Dar al-Kutub 'Ilmiyyah, 1997), p. 539.

${ }^{64}$ Syamsuddīn al-Żahabī, Tārìkh al-Islām wa Wafayāt Masyāhìr wa al-A'àm, vol. 48 (Beirut: Dār al-Kutub al-'Arabī, 1987), p. 59; Kathīr, al-Bidāyah wa al-Nihāyah, vol. 13, p. 286.

${ }^{65}$ Taghrībirdī, al-Nujūm al-Zähirah fi Mulūk Misr wa al-Qähirah, vol. 7, p. 222; Mūsā ibn Muḥammad al-Yūnīnī, Zail Mir'ät al-Zamān, vol. 2 (Cairo: Dar al-Kitab alIslamī, 1992), p. 365.

${ }^{66}$ Kathīr, al-Bidāyah wa al-Nihāyah, vol. 13, p. 272; Țabīb, Jāmi`a al-Tawārikh Rashidi, vol. 2, pp. 332-3.

${ }^{67}$ Kathīr, al-Bidāyah wa al-Nihāyah, vol. 13, p. 272; Jūzjānī, Tabaqāt-i-Nāṣirì, vol. 2, p. 1257. 
death of all Islamic empire without distinguishing which one is comrade and which is the opposite. He also destructed the caliphate without prior discussion to the Mongol Big Family, with the help of God, Ill call him to account for plenty of innocent blood. ${ }^{68}$

The above statement was Berke's response to the Hülegü's destruction of Baghdad and his execution of Caliph al-Musta'șim. It also supported Ahmed's view concerning Berke's protest against the Mongol's campaign to Baghdad "without distinguishing which one is comrade and which one is the opposite", showing the possible alliance between him and the caliph. This marked a subsequent historical dynamic of the Mongols in the aftermath of the destruction of the center of Islamic civilization. Along with the fragmentation of the Mongol vast territory that had been divided into several regions, political tension escalated in the big family of Mongol. In this case, one of the most notable was the Berke-Hülegü's civil war.

\section{Berke-Hülegü's Civil War}

Not only in the level of cold war, this internal strife continues to the open war. In this case, the Islamic-Mamluk role is also worthy of mention. After the destruction of Baghdad, Hülegü seized Syria. ${ }^{69} \mathrm{He}$ went to Egypt, but on the way, the Great Khan Möngke passed away. He then returned to Karakuram for the election of Möngke's successor and handed the troops to Naiman Kitbuga. The Mongols were intercepted by the Mamluk troops under the command of Sultan Qutuz who allied with Baybars, in Ain-e-Jalut. The battle took place on 3 September $1260 \mathrm{AD}$ with the major defeat of the Mongols, due to the absence of Hülegü and the reduction of Mongol army. ${ }^{70}$ It has become one of the key battles in history that determines the fate of Muslim world and the very existence of Islam as a whole, with the Mamluk as the last

${ }^{68}$ Țabīb, Jämi'a al-Tawärikeh Rashidi, vol. 1, p. 332; Nicolle, The Mongol Warlords, p. 99.

69 al-Fidā, Tärikh Abi al-Fidā' al-Musammā bi al-Mukhtasar fi Akbbār al-Basyar, vol. 3, pp. 199-204; Kathīr, al-Bidāyah wa al-Nihāyah, vol. 13, pp. 253-4.

70 Rasyīd al-Dīn, Jāmi' al-Tawārikh, vol. 2, p. 310-318; Ibn Kathīr, al-Bidāyah wa al-Nihäyah, vol. 13, p. 254, 262, 287. Țabīb, Jämi'a al-Tawärikh Rashidi, vol. 2, pp. 310-8; Kathīr, al-Bidāyah wa al-Nihäyah, vol. 13, pp. 254, 262, 287. 
fortress. Mamluk's victory over Kitbuga had raised much attention. Some proposed a unique answer related to the Berke's reinforcements to the Mamluk, by sending the military aid that contribute to defeat Kitbuga. ${ }^{71}$ Several historians have also proposed another explanation, namely the suitability of Mamluk horse-archers to the climate of the region, while the Mongol ponies, which were much smaller, were not suitable to face the extreme battle due to the heat of Syria. ${ }^{72}$

After the Mamluk succeeded in conquering the Mongols under Ketbuga, the tension then arose between Quțuz and Baybars. In the desert on the way back to Cairo, Quțuz was murdered due to the conspiracy of several emirs, including Baybars, and was probably under his leadership. ${ }^{73}$ The final result was that Baybars was proclaimed as the new sultan. ${ }^{74}$ After ascending the throne, Baybars realized that the backlash of Hülegü's forces to avenge the major defeat in Ain-e-Jalut might be much stronger and not easy to defeat. Baybars then took the initiative to forge his coalition with Berke Khan of the Golden Hordé and started to apply the anti-Ilkhan tendency. Being in the same position as muslim, Baybars invited Berke to break Ilkhan's power by waging a "holy war against the infidels" 75 and made a coalition with Golden Hordé in 1262 AD as stated earlier. The Baybars-Berke coalition was intertwined in $1262 \mathrm{AD}$ which is described as the waters of the Volga River flowing up to the Nile River.

As a consequence of Berke-Hülegü's disputes and the BerkeBaybars coalition, Hülegü intention to launch a counterattack towards the Mamluks, was also eventually confronted by Berke. In 1262 AD, the Golden Hordé troops unleashed some raids under the command of

71 Denis Sinor, "The Mongols and Western Europe", in A History of the Crusades: The Fourteenth and Fifteenth Centuries, vol. 3, ed. by Kenneth M. Setton (Madison: University of Wisconsin Press, 1975), p. 528.

72 Stephen Morillo, Jeremy Black, and Paul Lococo, War in World History: Society, Technology, and War from Ancient Times to the Present, vol. 1 (New York: McGraw-Hill, 2009), pp. 252-3.

73 Kathīr, al-Bidāyah wa al-Nihāyah, vol. 13, p. 257; Reuven Amitai-Preiss, Mongols and Mamluks: The Mamluk-Ilkhanid War, 1260-1281 (Cambridge: Cambridge University Press, 2004), p. 47.

${ }^{74}$ Kathīr, al-Bidāyah wa al-Nihāyah, vol. 13, p. 258.

75 James Chambers, The Devil's Horsemen: The Mongol Invasion of Europe (London: Book Club Associates, 1979), p. 154. 
Nogai Khan, Berke's commander in chief, against the Ilkhan troops in their territory. He succeeded in defeating Ilkhan's defense and successfully conquered Shirwan on August 1261 AD. Three months later, they also attacked Syiramun and massacred a lot of people there. Ilkhan staged a counter-attack on the same month and forced Nogai's troops to retreat. ${ }^{76}$

Hülegü ordered his troops to chase Nogai's army and took the offensive attack to the Berke's settlement by crossing Terek River. Having successfully crossed the river and reached the empty Kipchak encampment, they were attacked unexpectedly by Nogai troops. At the battle of Terek in the same year, Ilkhan's army suffered from defeat. They were finally ordered to retreat, due to the cold weather. The soldiers had to cross the frozen river, unfortunedly when they passed the ice, it suddenly broke and drowned many of the Ilkhanid troops. ${ }^{77}$

After this battle, a ceasefire took place in the intervening years of 1263-65 AD. During this time, the two armies prepared themselves for a fight. ${ }^{78}$ The war between the Golden Hordé against Ilkhan, reoccurred on January 8, 1265 AD. It became the last series of Berke-Hülegü's war. Hülegü moved northward to the Golden Hordés territory, where he died on his way there. Hearing the news of Hülegü's death, Berke immediately led 300.000 troops to attack the Ilkhan. However, they were intercepted by Hülegü's successor, Abagha Khan who succeeded in repelling Berke's troops from Ilkhan's territory. Ilkhan's army continued to lead the Golden Hordé troops to retreat to their demarcation. Upon the arrival at Tiflis, Berke died in 1266 AD and his entire army returned to the New Șarai. ${ }^{79}$ Golden Hordé-Ilkhanid war continued under each successor.

Along with the beginning of the Mongol's fragmentation marked by several civil wars, the battle of the Golden Hordé versus Ilkhan marked an important event of the anda battle (Mongol civil war) series which devided the Mongols in two groups; those who apply Yasaq (Mongolian customary law) and those who do not. The latter is represented by Golden Hordé that applied Islamic Sharia. The emergence of the protagonist

\footnotetext{
76 Ṭabìb, Jämi 'a al-Tawārikh Rashidi, vol. 2, p. 333.

77 Ibid., vol. 2, p. 335.

78 Amitai-Preiss, Mongols and Mamluks: The Mamluk-Ilkhanid War, 1260-1281, pp. $79-80$.

79 Chambers, The Devil's Horsemen, p. 158.
} 
figure of the Mongols made the history interesting, at that time, when Muslims became their victims and were powerless to get out of their intervention. Berke Khan's role for the Muslim world has become a kind of the savior from the "destroyer" of civilization. From this emerged the turning point of the historical relation between Mongols and Islamic civilization. The descendants of Chengiz Khan rewrite the Mongol's journey in Central Asia. Here, the emergence of the Islamic Mongol story found its momentum, where the descendants of Chengiz Khan rebuilt the house which was destructed by their ancestors.

\section{F. From Yasaq to Islamic Sharia: The Post-Baghdad Islamic Golden Age in Central Asia}

\section{The Shift and Fragmentation}

It goes without saying that the glory of Islam after the Baghdad's fall completely shifted to the Mamluk-Egypt which continued the 'Abbāsid lineage. Historical facts prove that the glory still continues in the Middle East region and even in the majority of Central Asia. It is not in the hands of Arab or Turk, yet another phase of Islamic civilization came under the Mongols; the descendants of Chengiz Khan himself. His descendants eventually contributed to the Islamic history of civilization with great achievements.

Started from Berke Khan of Golden Hordé, several Mongol rulers followed his footstep to embrace Islam and made it as the official religion of the state replacing the yasaq, which marked a new phase of Mongol history. One should note that 1260s was the starting point of the big fragmentation of Mongol Empire. It happened in two reasons: the fragmentation of creeds in one hand and the political upheaval in the other. From the very beginning, there were several creeds outside of the Tengrism, such as the indigenous Mongol religion which was embraced by the descendants of Chengiz Khan as the result of the cultural intersection between them and the culture of conquered regions, following the mass expansion throughout Asia and parts of Europe.

Although the establishment of such powers was based on the Mongol Law, after their leader claimed to convert to another religion, the seeds of different creeds appeared, in addition to Tengrism/ 
Göktanrı din, ${ }^{80}$ including Buddhism, Nestorianism, and Islam. Several historians consider this phenomena as the result of the tolerant and flexible characteristic of the Mongols regarding all religions, ${ }^{81}$ although Islam does not have a place in the Chengiz Khan era as good as other religions. It was reported that Chagatai showed some hostility toward Islam, particularly in regard to the matter of ablutions and the slaughter of cattle, where the precepts of the Islamic teaching were contrary to Mongol customs and to the yasaq. ${ }^{82}$ Among the Mongol leaders who respected or even convert to Buddhism are Kubilai Khan and most of his descendants. ${ }^{83}$ Those who embraced Nestorianism were Sorghaghtani Beki, Tolui's wife, the mothers of prominent Mongol leaders including Mongke, Kublai, Hülegü, and Ariq Boke, Doquz Khatun, Hülegü’s wife, and General Kitbuga, whereas who converted toward Islam was Berke Khan, as stated earlier, he was the first Muslim convert.

From the political point of view, the mass fragmentation of the Mongol was started from the anda battle or civil war among the Mongols. The death of Möngke, the Fourth Great Khan in 1259 AD, paved the way of internal polemic on the succession of the throne which escalated to the civil war between Toluid princes; Kublai Khan and Ariq Böke. The conflict took place in 1260-1266 AD, whereas Kaidu-Kublai war occured in 1268-1301 AD. In this case, Ariq Böke was supported by the majority of the royal family to become the Great Khan. The only Chengizid state that consistently supported Kubilai was Hülegü's kingdom, while Jöchids were initially the allies of Ariq Böke, in addition to Chaghtaids who had joined Ögedeid force under Kaidu against Kublai which had culminated in Kaidu-Kublai war in 1268-1301 AD. ${ }^{84}$

By this fragmentation, Hülegü had to face the Chaghataid princes in

80 The indigenous religion embraced by the Chingiz Khan and the Mongols in general was Tengrism, a Central Asian shamanistic religion which closed to Buddhism. They communicated with God through a shaman. See M. Abdul Karim, Islam Nusantara (Yogyakarta: Gama Media, 2013), p. 137.

81 Jack Weatherford, Genghis Khan and The Making of Modern World (New York: Three Rivers Press, 2004), p. 65.

82 Jūzjānī, Tabaqāt-i-Nāṣirì, vol. 2, pp. 1144-6.

83 See Grousset, The Empire of the Steppes, pp. 514, 627.

84 Thomas T. Allsen, Culture and Conquest in Mongol Eurasia (Cambridge: Cambridge University Press, 2001), p. 24. 
Khurasan and the Jöchid rivals in Caucasus. The major military encounter was fueled by Berke from Golden Hordé, a muslim convert who allied with Mamluk-Egypt, the rising Islamic dynasty that was the target of Hülegü's backlash after his major defeat in Ain-e-Jalut. This culminated in Berke-Hülegü war as explained earlier as one of the important event in the aftermath of Baghdad's fall. Shortly speaking, by that time, the Mongol empire had fragmented into four independent Khanates that have their own way of developing power, culture, including religion.

\section{The Islamic Mongol Dynasties; Political Dynamics and Major Cultural Achievements}

Started from Berke, certain Mongolian government was gradually influenced by Islamic teachings. To several extents, the original Mongolian law, yasaq, was replaced by a set of regulations based on the source of Islamic doctrines. ${ }^{85}$ One should note that in the time of their reigns, the peak of Islamic civilization continued to survive in the post-Baghdad era. Their palaces are inhabited by scholars, intellectuals, and thinkers as advisor for the rulers. They succeeded in building the Islamic glory in various fields. There are at least four Islamic Mongol Dynasties appeared in the aftermath of Baghdad's fall; Ilkhan (1256-1363 AD), Golden Hordé (1256-1506 AD), Chagatai (1227-1369 AD), and Timurid (1361-1506 AD).

Ilkhanate (1256-1363 AD)

85 One of the important issue that deserve to be examined as a separate study is the pattern of Islam among the Mongols. As the journey of Islamic da'wa spread around the world, acculturation is a necessity. In the Mongol case, there are at least three main issues in their conversion. First, they are mu'allaf originating from nomadic tribes, those who previously caused total destruction in the Islamic world. Second, Mongolian cultural identity which became their background was mixed with the Islamic doctrines with the Shi'ite character. Third, their media of conversion lies in the political level, not in the grass-roots movement. It remains problematic for the orthodox preacher like Ibn Taimiyyah who issued anti-Mongol fatwas when Ghazan Khan, a muslim convert, repeatedly attacked Syria. In spite of all, I keep the Mongols in mind as an integral part of the Islamic societies, as well as placing the Kharijites, Fatimid, Isma'iliyyah, and the like, as the members of the Islamic society as a whole, even though they were condemned by vast majority of Muslims themselves as the rebels. For further reading, see Denise Aigle, The Mongol Empire between Myth and Reality: Studies in Anthropological History (Leiden: Brill, 2015). 
It cannot be forgotten in history that Hülegü was also the founder of the Ilkhanate Empire, which covered the valleys of the Amu-Daria River to Syria and Caucasus through the Hindukush Mountains. Further, it marked one of the new phase of Islamic glory after the destruction of Baghdad. The word Il-khan in Mongol means the chief, in a special sense in the Mongol, it refers to the representative of the Great Khan in Karakuram, and also called the governor-general under the Great Khan, who has a vast territory of power and oversees several provinces. ${ }^{86}$ Hülegü, the destroyer of Baghdad, became the ruler of Persia and its surroundings as Il-khan (1256-1267 AD) in the days of Möngke and Kubilai Khan. At that time, especially at the time of Kublai, he began to organize his government. ${ }^{87}$

No one denies that Hülegü was identical to a tyrant when he destroyed one of the center of human civilization in Baghdad. However, it would also be unfair if he was judged as the man who ignored science, education, and scientific activities. Several excellent medieval muslim astronomers and polymaths, Nasīr al-Dīn al-Ṭūsi, Abu Bakar Sa'ad Janggi, Baha'uddin al-Din Lu'lu', and a leading historian «Ata Malik Juwaini, decorated his palace. Under the sponsor of Hülegü, al-Ṭūsi even set up the observatory in Maragha, the capital of Ilkhanate Empire, for the research purpose. ${ }^{88}$ The scientific achievements of Islam were transferred from Baghdad to Maragha through al-Tusi, one of the most important figures in the history of Islamic sciences who was the savior of the Greek treasure in Islamic world and the founder of internationallyrecognized "Ṭusi Couple" ${ }^{89}$ in the field of Astronomy and Mathematics. Accompanied by Hülegü, he came to Baghdad in 1263 AD, to bring some books from the schools and libraries there to the capital of Ilkhanate. ${ }^{90}$ This account refutes those who state that Hülegü has burned down all the books and flattened Baghdad with the ground. Rasyīd al-Dīn even

\footnotetext{
86 Ashrafuddin, Maddhajuger Muslim Itihas (1258-1800), p. 86.

87 Ṭabīb, Jämi 'a al-Tawärikh Rashidi, vol. 2, pp. 337-8.

88 Kathīr, al-Bidāyah wa al-Nihāyah, vol. 13, p. 249.
}

89 "A linear motion by means of one circle rolling inside another". John D. North, Cosmos: An Illustrated History of Astronomy and Cosmology (Chicago: Univ. of Chicago Press, 2008), p. 206.

90 Kathīr, al-Bidāyah wa al-Nihāyah, vol. 13, p. 281. 
praised Hülegü's devotion in philosophy, architecture, art, and alchemy. ${ }^{91}$

After Hülegü's death in 1265 AD, his son, Abagha Khan ascended the throne until his death in $1282 \mathrm{AD}$. The new political pages of the Ilkhanate started from the coronation of Tagudar Khan who replaces his brother Abagha in $1282 \mathrm{AD},{ }^{92}$ which started the Islamic pages in the history of Ilkhanate Empire. Tagudar converted to Islam and changed his name to Ahmad. ${ }^{93}$ He even sent a letter to the Sultan of Mamluk in Egypt primarily to make the coalition and recognition. ${ }^{94}$ However, his authority did not last long due to the great conspiracy from the leading Mongols. Backed by Kubilai, Arghun, the son of Abagha led a successful revolution against Tagudar until he was defeated, arrested, and executed in $1284 \mathrm{AD} .{ }^{95} \mathrm{He}$ was considered as the first Mongol martyr (syabid) for the sake of Islam. ${ }^{96}$ Later in succession, the Ilkhanate throne is held by Arghun (1284-1291), Gay Kathu (1291-1295), and Baydu (1295). Under these rulers, Ilkhanate Empire experienced the decline in many fields. ${ }^{97}$

Furthermore, the seventh Ilkhanate ruler, Mahmud Ghazan Khan, son of Arghun, has opened the total Islamic pages in the Ilkhanate's historical time-line. His regime (1295-1304 AD) was even marked by the establishment of Islam as the official religion of the state. ${ }^{98}$ He grew up in Buddhist environment. When his father, Arghun, became ascended the throne, the 10-years-old Ghazan was appointed as the Governor of Khurasan (Mazandaran and Ray) under the guidance of Amir Nawroz, who has served in many provinces of Persia with various positions since the time of Chengiz Khan and its successors for 39 years. ${ }^{99}$ He enjoyed

91 Țabīb, Jämi'a al-Tawärikh Rashidi, vol. 2, p. 337.

92 Khaldūn, Tärikh Ibn Khaldūn, vol. 5, p. 616.

93 Ibid.

94 Ibid.; Edward Granville Browne, A History Of Persian Literature Under Tartar Dominion (a.d. 1265-1502), vol. 3 (Cambridge: University Press, 1951), p. 26.

95 Ashrafuddin, Maddhajuger Muslim Itihas (1258-1800), p. 68.

${ }^{96}$ Browne, A History Of Persian Literature Under Tartar Dominion (a.d. 1265-1502), vol. 3, p. 26; Marco Polo, The Travels of Marco Polo, trans. by Ronald Edward Latham (Harmondsworth: Penguin Books, 1967), pp. 319-27.

97 Khaldūn, Tārikh Ibn Khaldūn, vol. 5, pp. 616-7.

98 Warren E. Preece and Philip W. Goetz (eds.), Encyclopaedia Britannica, vol. 7, 15th edition (Chicago: Encyclopaedia Britannica, 1979), p. 146.

99 Ibid. 
studying various religious disciplines that existed in his day. Under the guidance of Nawroz, who helped his fight against his cousin, Baydu, Ghazan and 100.000 Mongols made their testimony of the belief to convert to Islam, in front of Sadr al-Din Ibrahim, on June 19, 1295 AD. He fasted and recited the Qur'an in that year. ${ }^{100}$ In the early November, he added Mahmud as his first name. ${ }^{101}$

In addition, Ghazan also attempted the islamization among the Mongols themselves and implemented Sharia in his government. The period of his reign is recorded by history as the most secure and peaceful in which the intercultural harmony was firmly planted. Such a circumstance was depicted within a proverb, that in his reign, "tiger and deer are drinking water side by side". ${ }^{102}$ Ghazan was an independent leader whose conversion marked a very fundamental change in the Ilkhanate Dynasty. Not only attempted to Islamized the palace, he also unleashed the ties with the Great Khan in Peking. ${ }^{103}$

As a man of culture and learning, he rebuilt all institutions including schools, libraries, mosques, observatories, and the like. In the Ghazan Khan regime, rice production had a surplus and the Ilkhanate became the first exporting state in Mongol history. He revived the wheels of agriculture after a previously serious collapsed. It reduces and even exempts the taxes for the farmers. With the implementation of the irrigation system, farmers were eager and willing to return to the fields. A number of irrigation was also built, including a large canal in Hilla area. ${ }^{104}$ He died in 1304 AD. The Ilkhanate throne was succeeded by Öljaitü (1304-1316) and Abu Sa'id (1316-1335), before finally disintegrated in 1335 AD.

Golden Hordé (1227-1502 AD)

In Mongol history, the emergence of Golden Hordé marked as an

100 Kausar Ali, A Study of Islamic History (Dhaka: Ali Publications, 1979), p. 40.

101 Kathīr, al-Bidāyah wa al-Nihàyah, vol. 13, p. 401; Spuler, History of the Mongols, p. 71.

102 Ashrafuddin, Maddhajuger Muslim Itihas (1258-1800), pp. 74-5.

103 Ibid., pp. 86-8.

104 Ann K.S. Lambton, Continuity and Change in Medieval Persia: Aspects of Administrative, Economic and Social History, 11th-14th Century (Albany: SUNY Press, 1988), p. 184. 
interesting era due to its longest period (1227-1502 AD) compared to all Chengizid states. When Ögedei, the third son of Chengiz Khan, became the second Great Khan, there was a great conquest in the valleys of Volga River and Siberian regions. This conquest was led by Batu Khan, son of the Jöchi, which also marked the pioneering of the Kipchak Dynasty. When Batu's brother, Berke, reigned, this dynasty developed and transformed into the Golden Hordé Dynasty. ${ }^{105}$

The Batu's territory stretches from the Caucasus mountains from the south, the Black Sea from the east, including countries inhabited by the Slavs, to Northern Poland, along with the edges and surrounding areas of Akhluba River, Embu valley, and Lake Aral, in the west. ${ }^{106}$ The founder of this dynasty passed away in $1256 \mathrm{AD}$ when his son, Sartaq, was in Karakuram. Hearing the news of his father's death, Sartaq immediately headed for Sărāi. However, he also died on the way, so the brother of Batu, Berke Khan (1256-1267 AD), became his successor. Berke openly declared as muslim. His openness in recognizing his self as an adherent of Islam made a lot of people follow his footsteps, to convert to Islam. ${ }^{107}$ He also built many mosques, and school in every corner. He also has a very close relationship with the "ulama and fuqaha. ${ }^{108}$

Berke preceded Ghazan Khan in replacing Yasaq with Islamic Sharia as the state official regulation. He also considered as the protector and the savior of Islam. He died in 1267 AD after a war against Abagha, son of Hulagu in Tiflis (1266). After Berke, the rulers of Golden Hordé were Mongke Timūr (1267-1280), Tuda Mongke (1280-1287), Tula Bugha (1287-1290), and Tokhtuh/Tokhtagha (1290-1313). ${ }^{109}$ In the post-Berke period, there was no special leader and their detailed narratives are rarely found in historical sources.

Similar with the case of Ilkhanate, the course of early $14^{\text {th }}$ century has witnessed the total Islamic turn in Golden Hordé. The nephew of

105 Masudul Hasan, History of Islam (Delhi: Adam Publishers \& Distributors, 1992), p. 29.

106 Ashrafuddin, Maddhajuger Muslim Itihas (1258-1800), p. 85.

107 Ibid:; Arnold, The Preaching of Islam: A History of the Propagation of the Muslim Faith, pp. 227-8.

108 Khaldūn, Tärikh Ibn Khaldūn, vol. 5, p. 603.

109 Spuler, History of the Mongols, pp. 209-10. 
Tokhtu and Timūr's grandson, son of Toghrilcha, Uzbeg Khan, ascended the Throne in New Șarai (1313-1341 AD). In the beginning, Uzbeg was a pagan before finally converting to Islam. His conversion was a great victory for Islam. ${ }^{110}$ Although Berke or Tuda Mongke previously converted to Islam, the majority of the Golden Hordé remained pagan. In addition to his conversion, he also made all the Mongols and Kipchak embraced Islam. In the second decade of the $14^{\text {th }}$ century AD, the those who converted to Islam are greatly increasing. ${ }^{111}$ From Uzbeg onwards, the khans of the Golden Hordé were all Muslim.

Uzbeg was recorded by history as a very staunch Muslim. His period is recorded as the peak of Golden Hordé achievement. During his time, state administration was applied in accordance with Islamic Sharia. ${ }^{112}$ Uzbeg was also a man of art and literature. At that time, the atmosphere of life with a very high culture reached its peak in Golden Hordé. He also established many beautiful buildings, including mosques and schools. Traders came from all over the world, including China, passing through the Baltic Sea. At the time of Uzbeg, the Golden Horde was the meeting point of various cultures in Eurasia. He was a pluralist and tolerant Islamic leader who created a multi-cultural circumstance. He even made a friendship with the Christians by allowing the Venetians to establish a colony near the Don River and performing another interfaith policy. ${ }^{113}$

After Uzbeg, the throne was inherited by Tini Beg (1341-1342), a Christian, and Jani Beg (1342-1357). Entering the decade of 1340s, the Black Death weakened the Golden Horde economy. Jani Beg died of the plague. After that, several wars for the throne took place resulting in the defeat of Batu's family by their political opponents. ${ }^{114}$ The throne handled by Birdi Beg (1359-1360) and Nawroz (1360-1361). From Nawroz up to 1380 , there were 15 weak Khanates ascended the throne of Golden

110 Hasan, History of Islam, p. 105.

111 Ibid.

112 Abū al-Fidā Ismā’il Ibn Kathīr, al-Bidāyah wa al-Nihāyah, vol. 14 (Giza: Hijr li al-Tiba'ah wa al-Nasyr, 1998), p. 77.

113 Hasan, History of Islam, p. 105.

114 Ibid.; Abū al-Mahāsin Yūsuf Ibn Taghrībirdī, al-Nujūm al-Zāhirah fi Mulūk Misr wa al-Qāhirah, vol. 10 (Cairo: Mațba'a Dār al-Kutub wa-al-watā’iq al-qawmiyya, 1971), p. 74. 
Horde. Mamai, the last of these Khanates suffered several defeats and lost some vassal states, including Russia. The palace was collapse again by the war for the throne. ${ }^{115}$ After that, Tokhtamish ascended the throne with the assistance of Timur Lank and re-established the Golden Horde. He restored the sovereignty of Russia in $1382 \mathrm{AD}$. He died in obscurity in $1405 \mathrm{AD}$ after his disputes with Timur which led to the brutal destruction of New Șarai.

After Toktamish, Idhiku Khan became the last ruler of Golden Horde until his death in 1419 AD. Thereafter, the Golden Horde's territory disintegrated into several small dynasties; Kazan (1437-1557), Austrakhan (1466-1566), and Crimea (1420-1783). New Ṣarai was totally destructed by Russia in $1502 \mathrm{AD}^{116}$ It marked the end of Islamic Mongol's power in Eurasia.

\section{Chaghatai (1227-1369 AD) and Timurid ("1369”-1506 AD)}

It has been mentioned that after the death of Genghis Khan, Chaghatai became the ruler of Transoxiana since 1227 AD. In spite of his hostility toward Islam, it was reported that one of his ministers in charge of all government affairs was Karachar Nevian, a Muslim from Transoxiana. ${ }^{117}$ After his death in 1242 AD, his grandson, Qara Hülegü, came to power at Transoxiana. However, he was fired by Kayuk, the $3^{\text {rd }}$ Great Khan of the Mongols who replaced him by the fifth son of Chaghatai, Yesü Möngke. Due to his involvement in the overthrow the Great Khan, Yesü Möngke was also fired by Ghuyuk Khan. Subsequently, Qara Hülegü was again appointed as a ruler of Transoxiana in 1251 AD. In that year, he died suddenly and his wife, Orghana, performed her husband's duties as a temporary official. Several historians assumed that Orghana was a Muslima. ${ }^{118}$

After Orghana, his son, Mubarak Shah, became the first Muslim to rule in the dynasty in $1266 \mathrm{AD}$. In the history of Mongol-Caghatai,

115 Taghrībirdī, al-Nujūm al-Zähirah fi Mulūk. Misr wa al-Qāhirah, vol. 10, p. 74; Ashrafuddin, Maddhajuger Muslim Itihas (1258-1800), p. 87.

116 Ashrafuddin, Maddhajuger Muslim Itihas (1258-1800), pp. 86-8; Ali, A Study of Islamic History, pp. 44-5, 139-41.

117 Edward Green Balfour (ed.), Encyclopedia of India and of Eastern and Southern Asia, vol. 5 (Madras: the Scottish \& Adelphi presses, 1873), p. 145.

118 Ashrafuddin, Maddhajuger Muslim Itihas (1258-1800), p. 95. 
Mubarak Shah was also the first ruler of the Mongols to use the Islamic name. His fate was not lucky enough. He dropped by his cousin, Buraq Khan, who also cannot last long in holding power as he was overthrown by Kaydu, the Great Khan's cousin. ${ }^{119}$

After Buraq Khan died 1271 AD, with the support of Kaydu, Nikopai, grand-daughter of Chaghatai became the ruler of Transoxiana. He was replaced by Buqa Timūr (Chaghatais son). After he died in 1282 AD, Buraq Khanss second son, Duwa Khan, ascended the throne until he died in $1307 \mathrm{AD}$. His reign was the longest one in the time-line of the Chaghatai dynasty. In his time, the Chaghatai dynasty reached its peak, although Duwa and Kaidu were involved in several disputes.

Furthermore, Duwa Khan's three sons became the successors of the Chaghatai Dynasty; Ishen Buqa (1309-1318 AD), Khan Kabak (1318-1326 M), and Tarmashirin (1226-1334 AD). Among them, Tarmashirin was the most popular and successful in running the wheels of the Chaghataid Government. Tarmashirin decided to convert to Islam following Mubarak Shah. He used the name 'Alauddin. At the end of his reign, there were many riots and rebellions, especially from his nephew, Buzan. After Tarmashirin died, there was a great confusion of power, both in Transoxiana and in the Chaghatai Dynasty. Between 1334 and 1369, 17 consecutive rulers became the Khan in Transoxiana. They were very weak and unable to recover the situation. It led to extraordinary blood-shed and brought this dynasty to the gate of destruction. In these bad times, Timur or Tamerlane appeared to seize the power of the Chaghatai Dynasty. ${ }^{120}$

When Timur came to power at Transoxiana, there was a Chagahtaid ruler named Tura Khan who was very incompetent and ruled as a puppet with no power. Timur took the advantages of this situation by giving him high salary. He was immersed in luxury and Timur finally became the Chaghtaid ruler, opening the new pages of the history of Central Asia called the Timurid Empire. ${ }^{121}$

Timur was a Turco-Mongol ruler who remained a representative

$\begin{array}{ll}119 & \text { Ibid. } \\ 120 & \text { Ibid., pp. 96-7. } \\ & \\ 121 & \text { Ibid. }\end{array}$


of the Chaghataid from his mother lineage. ${ }^{122}$ He became the connector of the dynasty's existence which was powerless. The most important was Timur's contribution to revive the dynasty with the Islamic identity. He was an ambitious leader who wanted to rule the whole world like Chengis Khan and Alexandar the Great. He once said "The lord of the heavens is Allah and there is only one single ruler on this earth, that is me". ${ }^{123}$ To speak about him is to remind his internationally-recognized great conquests.

With that ambitions, he seized Persia, Sijistan, Azarbayjan, and Georgia. In Isfahan, he piled up 70,000 human skulls. He also controlled and destroyed Qara-Qoyunlu. The ruler of that region, Qara Yusuf fled and requested political asylum to Bayazid, the Sultan of Ottoman. After that, he also seized Fars, the capital of the Muzaffariah Dynasty. In the town of Shiraz, he committed a mass murder in 1393 AD, before he conquered Baghdad. He destroyed those areas and wiped out the whole city in a very cruel way. He slaughtered the people inhumanely, including women and children. ${ }^{124}$

Timur attacked the Russians insistently and forced Tukhtamish, the second founder of Golden Hordé, to surrender his territory. He also seized the city of Delhi in 1398 AD. At that time, he challanged Bayazid of Ottoman who was also an ambitious and powerful Muslim ruler. This was the result of the political asylum provided by Bayazid to Qara Yusuf, one of Timur's enemies. He offensively attacked Anatolia with 250.000 soldiers and expelled the Ottoman Turks in a devastating war in Anggora (modern Ankara), resulting the total defeat of Bayazid who died in Timur's prison in 1403 AD. Besides, Timur also conquered Aleppo and forced the Mamluk army to surrender to him in Damascus by paying tributes. ${ }^{125}$ All of Asia Minor belonged to him. Timur's last expedition was to China in his old age. Bad weather caused the dying of vast majority of his troops. He was tired and eventually suffered from illness on the banks of the Jaxartes River. Timur died on February 18,

122 Ashrafuddin, Maddhajuger Muslim Itihas (1258-1800), p. 99; Ali, A Study of Islamic History, pp. 1-3.

123 Ali, A Study of Islamic History, pp. 127-8.

124 Lothrop Stoddard, Dunia Baru Islam (Jakarta: Panitia Penerbit, 1966), p. 24.

125 Ali, A Study of Islamic History, pp. 54-61. 
$1406 \mathrm{AD}$ on his way to attack China. ${ }^{126}$

In addition to the stories about his cruelty on the battlefield, it cannot be denied that the dynamic of Islamic civilization in Timur's reign has also reflected one of the best achievement. Before his time, the Chaghatai Dynasty, however, has built many new towns and palaces in the Transoxiana, including Isikkul and Talash, two well-known cities, the political center of the Chaghataid, in addition to the "Nakh Shab" Palace. ${ }^{127}$

As a muslim, Timur built many mosques, hospitals, and schools. The architectural field was one of his legacy in the Islamic world. The building that was prepared before Timur's death was the tomb of Gure-Mir, a beautiful mausoleum for Timurid royal family which became the model for Persian-Mongolian architecture. He also paid special attention to the welfare of farmers and the facilities of traders. In his time, the merchants were very busy, passing through the River Amu Daria, Euphrates, Tigris, Sind, and so forth. Commodities from Arabia even from Africa and Europe were supplied to Samarkand and Tabriz. Both cities were considered as the most prosperous and beautiful cities of the Middle Ages. ${ }^{128}$

His palace was decorated by jurists, astronomers, sociologists, historians, doctors, and humanists. He built many palaces, mosques, and beautiful buildings. He exchanged ideas with poets and scientists in these places. Historians recognize the city of Samarkand as one of the beautiful city that attracted the visitors from all over the world. He was also very respectful to the scientists and poets. Scientists from the conquered lands were greatly appreciated. They include Maulana Fazal, Maulana Nizāamuddin (Timur's private doctor), and, Zafar Nama, a historian. He once also met Ibn Khaldun when he conquered Damascus. Timur was not only famous as the conqueror of the nation, he was also a conqueror of various languages, such as Chaghataid, Turkey, Persian, and Mongolian. His famous writings, Malfurāt-e-Timuri, has proved that

126 Ivar Lissner, The Living Past, trans. by J. Maxwell Brownjohn (London: Jonathan Cape, 1957), p. 203; Ali, A Study of Islamic History, pp. 71-5; Spuler, History of the Mongols, p. 211.

127 Ali, A Study of Islamic History, p. 55.

128 Ibn Battuta, Travels in Asia and Africa 1325-1354, trans. by H.A.R. Gibb (London: George Routledge., 1953). 
he was not only a skilled war-man but also a learned man. ${ }^{129}$

After Timur, none of his descendants are competent in running the government. They fight each other for the power. Toward the death of Timur, his eldest son, Peer Muhammad was appointed as the crown prince, but his grandson, Khalil Shah, precisely ascended the throne (1406 AD) in Samarqand. After that, the fourth son of Timur, Shahrukh, became the ruler of Herat to replace the previously exiled Khalil. He did not want to expand the territory like his father, but he wanted to build, including the areas his father had destroyed. At the time, the whole country became prosperous. Shahrukh was the first to build an academy for research and teaching of science, especially science, art, literature, and music. Many humanists also gathered in his court. ${ }^{130}$

After Sharuk's death, his son, Ulugh Begh, rose up. He followed in his father's footsteps. He built a famous observatory that still survives until today. This period reached a golden age in the arts and culture. $\mathrm{He}$ is a populist and pious ruler. However, he was less-alert in terms of politics and was eventually killed by his own son, Abdul Latif, who seized the power. He also did not last long because he was also killed by Baba Hussein. After that, Shahrukh's grandson, Babur, ruled Khurasan during two years and made various innovations. ${ }^{131}$

Further, Abu Sa'id, the grandson of Timur's third child, ascended the throne. Among the descendants of Timur, he was the most committed leader in implementing the Islamic Sharia. His period was the triumph of the tariqah, which led to the Sufis and clerics gathered in his palace. He died in a respectively battle in $1467 \mathrm{AD}$, and was replaced by Ahmad and Mohammed. The last ruler of this dynasty was Baykara, Shahrukh's grandson. He controlled politics and founded the capital in Herat. In this period the royal monarchy recovered. At that time, there were many emerging scientists, poets, painters, and humanists. He reigned for 37 years and died in $1506 \mathrm{AD}$. The death of Baykara ended of the power of the Timurid Dynasty with all of its achievements. ${ }^{132}$

\footnotetext{
129 Ashrafuddin, Maddhajuger Muslim Itihas (1258-1800), p. 117.

130 Ali, A Study of Islamic History, p. 87.

131 Ibid., pp. 80-5.

132 Ibid.
} 


\section{G. Concluding Remarks}

The exploration on Baghdad's fall and subsequent historical events led to several concluding remarks. First, the fall of Baghdad to the Mongols is deeply linked to the multi-dimensional political crisis in Central Asia as well as the fragile internal state of Abbasids. Some of the complex explanations mentioned by historians related to external factors of the destruction of Baghdad ranged from the Otrar incident that marked the destruction of the last Abbasid stronghold in Central Asia, to al-'Alqami's conspiracy. Second, the destruction of Baghdad by Hülegü Khan coincided with the fragmentation among the Mongols. Some of their leaders had embraced Islam, started by Berke Khan of the Golden Hordé that led to a civil war between the fellow Mongols, including the famous Berke- Hülegü's civil war, which was one of the aftermath effect of Hülegü's destruction of Baghdad. Berke's blockade of Hülegü was regarded as patriotic stance that saved the Islamic world from further destruction by the Mongols. Third, the Chengiz Khan descents in Central Asia ultimately paid back to what his predecessors had done; bringing the glory of Islam once again in the region. This is marked by the emergence of the Mongol Dynasty of Islam that developed after the destruction of Baghdad in Central Asia with a myriad of achievements. 


\section{BIBLIOGRAPHY}

Aigle, Denise, The Mongol Empire between Myth and Reality: Studies in Anthropological History, Leiden: Brill, 2015.

Algar, Hamid, "Introduction", in The Path of God's Bondsmen from Origin to Return, trans. by Hamid Algar, New York: Caravan Books, 1982.

Ali, Kausar, A Study of Islamic History, Dhaka: Ali Publications, 1979.

Allsen, Thomas T., Culture and Conquest in Mongol Eurasia, Cambridge: Cambridge University Press, 2001.

Amitai-Preiss, Reuven, Mongols and Mamluks: The Mamluk-Ilkhanid War, 1260-1281, Cambridge: Cambridge University Press, 2004.

Arnold, Thomas Walker, The Preaching of Islam: A History of the Propagation of the Muslim Faith, London: Constable and Company, 1913.

Ashrafuddin, Ahmed, Maddhajuger Muslim Itihas (1258-1800), Dhaka: Nawrose, 1976.

Asimov, M.S. and C.E. Bosworth (eds.), History of Civilizations of Central Asia, vol. 4, Paris: UNESCO Publishing, 2000.

Balfour, Edward Green (ed.), Encyclopedia of India and of Eastern and Southern Asia, vol. 5, Madras: the Scottish \& Adelphi presses, 1873.

Battuta, Ibn, Travels in Asia and Africa 1325-1354, trans. by H.A.R. Gibb, London: George Routledge., 1953.

Bira, Sh., "The Mongols and Their State in the Twelfth to the Thirteenth Century", in History of Civilizations of Central Asia, vol. 4, ed. by M.S. Asimov and C.E. Bosworth, Paris: UNESCO Publishing, 2000.

Bosworth, C.E., "The Appearance of the Arabs in Central Asia Under the Umayyads and the Establishment of Islam", in History of Civilizations of Central Asia, vol. 4, ed. by M.S. Asimor and C.E. Bosworth, Paris: UNESCO Publishing, 2000.

Boyle, J.A., "Dynastic and Political History of the Il-Khāns", in The Cambridge History of Iran, vol. 5, ed. by J.A. Boyle, Cambridge: Cambridge University Press, 1968.

Browne, Edward Granville, A History Of Persian Literature Under Tartar Dominion (a.d. 1265-1502), vol. 3, Cambridge: University Press, 1951. 
Chambers, James, The Devil's Horsemen: The Mongol Invasion of Europe, London: Book Club Associates, 1979.

Cooperson, Michael, "Baghdad in Rhetoric and Narrative", Muqarnas, vol. 13, no. 1, 1996, pp. 99-113 [http://dx.doi.org/10.1163/2211899390000359].

Daftary, Farhad, The Ismäcilis: Their History and Doctrines, Cambridge: Cambridge University Press, 1990.

DeWeese, Devin, Islamization and Native Religion in the Golden Horde: Baba Tükles and Conversion to Islam in Historical and Epic Tradition, Pennsylvania: The Pennsylvania State University Press, 2007.

al-Fidā, Abu, Tärikeh Abi al-Fidä̀ al-Musammä bi al-Mukhtasar fi Akbbār al-Basyar, vol. 3, Cairo: al-Matba'ah al-Husainiyya al-Mishriyya, 1907.

Gilli-Elewy, Hend, "Al-awādi al-ğāmia: A Contemporary Account of the Mongol Conquest of Baghdad, 656/1258", Arabica, vol. 58, no. 5, 2011, pp. 353 - 371 [http://dx.doi.org/10.1163/157005811X561569].

Grousset, René, The Empire of the Steppes: A History of Central Asia, trans. by Naomi Walford, New Brunswick: Rutgers University Presss, 1970.

Hasan, Hasan Ibrahim, Tarikh al-Isläm; al-Siyasi wa al-Dini wa al-Tsaqafi wa al-Ijtima’i, vol. 4, Beirut: Dar al-Jil, 1996.

Hasan, Masudul, History of Islam, Delhi, India: Adam Publishers \& Distributors, 1992.

Hitti, Philip K., History of the Arabs, London: Macmillan, 1937.

Ibn al-Ṭiqțaqā, Muhạmmad b. Alī, al-Fak'rì fì al-Adāb al-Sultāniyya wa-alDuwal al-Islāmiyya, Beirut: Dār Șādir, 1980.

Jr, John Masson Smith, "Hülegü Moves West: High Living and Heartbreak on The Road to Baghdad", in Beyond the Legacy of Genghis Khan, ed. by Linda Komaroff, Leiden: Brill, 2006.

Juvaini, Ata-Malik, Genghis Khan: The History of the World Conqueror, trans. by J.A. Boyle, Manchester: Manchester University Press, 1997.

Jūzjānī, Minhāj Sirāj, Tabaqāt-i-Nāsisiri, vol. 2, trans. by H.G. Raverty, New Delhi: Mrs Nirmal D. Jain for Oriental Books Reprint Corporation, 1970.

Karim, M. Abdul, Islam Nusantara, Yogyakarta: Gama Media, 2013. 
Kathīr, Abū al-Fidā Ismā’il Ibn, al-Bidāyah wa al-Nihäyah, vol. 13, Giza: Hijr li al-Tiba'ah wa al-Nasyr, 1998.

----, al-Bidāyah wa al-Nihāyah, vol. 14, Giza: Hijr li al-Tiba'ah wa al-Nasyr, 1998.

Khaldūn, Abdurrahmān Ibn, Tärikh Ibn Khaldūn, vol. 5, Beirut: Dar AlFikr, 2000.

Lambton, Ann K.S., Continuity and Change in Medieval Persia: Aspects of Administrative, Economic and Social History, 11th-14th Century, Albany: SUNY Press, 1988.

Le Strange, G., Baghdad during the Abbasid Caliphate: From Contemporary Arabic and Persian Sources, New York: Cosimo Classic, 2011.

Lewis., Bernard, Islam from the Prophet Muhammad up to the Capture of Constantinople, vol. 1, New York: Harper Torchbook, 1974.

Lewis, Bernard, “'Abbāsids", Encyclopaedia of Islam, vol. 1, ed. by H.A.R. Gibb and et. al, Leiden: Brill, 1992.

Lewis, Bernard., Arabs in History, Oxford: OUP Oxford, 2002.

Lissner, Ivar, The Living Past, trans. by J. Maxwell Brownjohn, London: Jonathan Cape, 1957.

Litvinsky, B.A. and Zhang Gua-da, "Historical Introduction", in History of Civilizations of Central Asia The Crossroads of Civilizations: A.D. 250-750, vol. 3, ed. by B.A. Litvinsky, R. Shabani Samghabadi, and Zhang Gua-da, Paris: UNESCO Publishing, 1996.

Lubis, Haji Muhammad Bukhari, "The Role of Sufis in Vonverting the Mongols into Islam", Islämiyyät, vol. 8, 1987.

Maqrīzī, Taqīaddīn Aḥmad b. 'Alī al-, al-Suluk li Ma'rifat Duwal al-Muluk, vol. 1, Beirut: Dar al-Kutub 'Ilmiyyah, 1997.

Morgan, David, The Mongols, Cambridge: Wiley-Blackwell, 1993.

Morillo, Stephen, Jeremy Black, and Paul Lococo, War in World History: Society, Technology, and War from Ancient Times to the Present, vol. 1, New York, NY: McGraw-Hill, 2009.

Nicolle, David, The Mongol Warlords: Genghis Khan, Kublai Khan, Hulegu, Tamerlane, New York: Firebird Books, 1990.

North, John D., Cosmos: An Illustrated History of Astronomy and Cosmology, 
Chicago: Univ. of Chicago Press, 2008.

Polo, Marco, The Travels of Marco Polo, trans. by Ronald Edward Latham, Harmondsworth: Penguin Books, 1967.

Preece, Warren E. and Philip W. Goetz (eds.), Encyclopaedia Britannica, vol.

7, 15th edition, Chicago: Encyclopaedia Britannica, 1979.

Rahman, M. Lutfur, Islam, Dhaka: Bangla Academy, 1977.

Ruysbroeck, Willem van, The Mission of Friar William of Rubruck: His Journey to the Court of the Great Khan Möngke, 1253-1255, trans. by Peter Jackson, London: Hakluyt Society, 1990.

al-Salabi, 'Ali Muhammad, al-Ayyubiyyun ba'da Salāh al-Dìn, Beirut: Dār al-Ma'rifah, 2001.

Savory, Roger, "Baghdad", Encyclopaedia of Islam, vol. 1, ed. by H.A.R. Gibb and et. al, Leiden: Brill, 1992.

Sevim, A. and C.E. Bosworth, "The Seljuqs and the Khwarazm Shahs", in History of Civilizations of Central Asia, vol. 4, ed. by M.S. Asimov and C.E. Bosworth, Paris: UNESCO Publishing, 2000.

Sinor, Denis, "The Mongols and Western Europe", in A History of the Crusades: The Fourteenth and Fifteenth Centuries, vol. 3, ed. by Kenneth M. Setton, Madison: University of Wisconsin Press, 1975.

Spuler, Bertold, History of the Mongols: Based on Eastern and Western Accounts of the Thirteenth and Fourteenth Centuries, trans. by Helga Drummond and Stuart Drummond, London: Routledge \& Kegan Paul, 1972.

----, "The Disintegration of the Caliphate in the East", in The Cambridge History of Islam, vol. 1A, ed. by P.M. Holt et al., Cambridge: Cambridge University Press, 1977.

Stoddard, Lothrop, Dunia Baru Islam, Jakarta: Panitia Penerbit, 1966.

Ṭabīb, Rashīd al-Dīn, Jāmi'a al-Tawārikh Rashidi, vol. 1, Qum: Wizārah al-Tsaqāfah al-Irsyād al-Qaumi.

----, Jāmi'a al-Tawārikh Rashidi, vol. 2, Qum: Wizārah al-Tsaqāfah al-Irsyād al-Qaumi.

Taghrībirdī, Abū al-Mahāsin Yūsuf Ibn, al-Nujūm al-Zāhirah fi Mulūke Misr wa al-Qähirah, vol. 7, Cairo: Maṭba'a Dār al-Kutub wa-al-watā’iq al-qawmiyya, 1971. 
Muhammad Abdul Karim

----, al-Nujūm al-Zähirah fi Mulüke Misr wa al-Qähirah, vol. 10, Cairo: Maṭba'a Dār al-Kutub wa-al-watā’iq al-qawmiyya, 1971.

Watt, W. Montgomery, Kejayaan Islam: Kajian Kritis dari Tokob Orientalis, trans. by Hartono Hadikusumo, Yogyakarta: Tiara Wacana, 1990.

Weatherford, Jack, Genghis Khan and The Making of Modern World, New York: Three Rivers Press, 2004.

Woods, John E., "A Note on the Mongol Capture of Ișfahān”, Journal of Near Eastern Studies, vol. 36, no. 1, 1977, pp. 49-51.

al-Yūnīnī, Mūsā ibn Muhammad, Zail Mir'āt al-Zamān, vol. 1, Cairo: Dar al-Kitab al-Islamī, 1992.

----, Zail Mir'àt al-Zamān, vol. 2, Cairo: Dar al-Kitab al-Islamī, 1992.

al-Zahabi, Syams al-Din, al-'Tbarfi Khabari Man Ghabar, vol. 2, Beirut: Dār al-Kutub 'Ilmiyyah, 1985.

al-Żahabī, Syamsuddīn, Tārìkh al-Islām wa Wafayāt Masyāhìr wa al-A'lām, vol. 48, Beirut: Dār al-Kutub al-‘Arabī, 1987. 